\title{
Correction to: An Activity-based Design Case for Step-by-step Teaching of Programming to Secondary School Students
}

\author{
Ali Kürşat Erümit
}

\section{Correction to:}

Chapter 35 in: M. J. Bishop et al. (eds.), Handbook of Research in Educational Communications and Technology, https://doi.org/10.1007/978-3-030-36119-8_35

The original version of this chapter was inadvertently published with the incorrect names of people in the text narrative.

The names written in Chapter ("Kürşat", "Güven”, "Ayşegüll, "Dilara” and "Ali”) are real names. These names ("Kerem" instead of "Kürşat", "Hüseyin" instead of "Güven", "Ceren" instead of "Ayşegül", "Semra" instead of "Dilara", "Yahya" instead of "Ali") has been updated in this version.

The updated online version of this chapter can be found at https://doi.org/10.1007/978-3-030-36119-8_35 